\title{
An Empirical Evaluation of Key Factors Affecting Mobile Shopping in India
}

\author{
Vikram Kumar Sharma, Arun Kumar Singh
}

\begin{abstract}
The word 'Shopping' was originated from the French word eschoppe which means leaning in front of a booth. Since 16 th century the word is going circles in the society. Now a days Shopping means to explore and buy goods in the exchange of money. For years it's like a buzzword in the households. In the era of mobile technology revolution and the advent of regulatory framework, the way we shop has changed dramatically. Mobile technology has created a new paradigm in retail industry. The customized approach and the convenience of shopping through handsets are making the overall experience effective. The Purpose of this paper is to study the imperatives of Indian consumers' to avail mobile shopping services and to develop a Mobile Shopping Acceptance Model. Three constructs i.e Attitude towards Behaviour, Subjective Norms and Perceived Behavioural Control are used for the purpose. Theory of Planned Behaviour (TPB) and Innovation Diffusion Theory (IDT) are used to develop the Model. The Model was validated using Factor Analysis and Hypothesis Testing.
\end{abstract}

Index Terms: Acceptance Model, Consumer Behaviour, Decision preferences Mobile Shopping, TRA, TPB, Technology Cluster

\section{INTRODUCTION}

The word 'Shopping' was originated from the French word eschoppe which means leaning in front of a booth. Since 16th century the word is going circles in the society. Now a days Shopping means to explore and buy goods in the exchange of money. For years it's like a buzzword in the households. In the era of mobile technology revolution and the advent of regulatory framework, the way we shop has changed dramatically. Mobile technology has created a new paradigm in retail industry. The customized approach and the convenience of shopping through handsets are making the overall experience effective. The expectation as well as trust of customers has increased and now they want quick response to their shopping needs. With the rise of companies like Flipkart and Amazon the trust levels has increased. The real time interaction, smart purchases, customization and convenience is providing completely differentiated one touch shopping experience (Kiseol Yang, 2010). More and more customers are engaging themselves into mobile shopping. Now the answer to why the customers do, what they do is explained by the models of TRA (Theory of Reasoned Action) and TPB (Theory of Planned Behaviour). The TRA was developed by Martin Fishbein and Icek Ajzen in 1967. This study discusses the key factors which build behaviour in customers to shop more through handsets with one touch experience. It will help the businesses to understand the factors which influence the customers to move to mobile shopping sites. The outline of the Research Paper is as follows:

Section I is all about introducing the concepts related to the study. Section II discusses the Literature Review and identifying the Research gap. Section III tells about the objectives of the study. Section IV is about the Research Methodology used. Section V explains the results and analysis part with research model and all. Section VI is last but not the least. It is devoted towards the Conclusion \& Discussion. And finally the study is concluded with the References.

\section{LITERATURE REVIEW}

In the field of Research and Investigation Models like Technology Acceptance Model (TAM) (1989 Davis), Theory of Planned Behaviour (TPB) (1975 Fishbein and Ajzen), and Innovation diffusion theory (IDT) (1995 Rogers) are very popular. These models are used extensively. The current study uses TPB and IDT to study the Intention of consumers to shop through mobiles. Varnali and Toker (2010), and Shankar et al. (2010) studied the mobile marketing and attitudes of customers towards their mobile phones. Now a day's Mobiles are considered as inseparable from the user though the customers though they feel marketing messages as kind of encroachment into their personal tech space (Muk, 2007; Samanta et al., 2009). So the Marketers are thinking of new ideas to customers to grant "access". According to a survey conducted by Market Intelligence Center (MIC) the number of mobile phone subscribers were increased from 524.9 million to 813.2 million from 2013 to 2018 , almost 16 percent compounded growth. Thus there is a huge potential for mobile shopping services to flourish. The growth in number of mobile users led to the decline of voice calls tariffs but the cellphone related services like chats, mobile shopping increased gradually. It is seen as a new opportunity for service providers to increase their revenue (Kuo and Yen, 2009). Though it must be understood that the mobile shopping is still in its initial stages thus a better understanding of factors that affects the Mobile shopping behaviour is needed.

Revised Manuscript Received on July 5, 2019.

Vikram Kumar Sharma, Assistant Professor, Management Studies, JEMTEC, Greater Noida, India,

Dr. Arun Kumar Singh, Professor (HOD), Management Studies, JEMTEC, Greater Noida, India. 
(Sarker and Wells, 2003) discovered that understanding of the motivations and circumstances that led to the perception of consumers is clearly missing from the context. Also the success of Mobile Commerce is guaranteed with the development of a sustainable network system (Sivunen and Valo, 2012). One of the studies by (Perse, 1986; Rubin, 1981) found that Online Media is an important part of individual's life. Though studies on electronic media showed it as an crucial parameter that affects dependency and intention to purchase (Bigne et al., 2007; Ruiz and Sanz, 2013), only a limited work is there on Mobile shopping behaviour. To continue with the discussion there is a concept called Technology Cluster. The concept was examined for the acceptance of e-commerce (Eastin, 2002), M-internet (Cheong and Park, 2005) and mobile commerce (Yang, 2005). Technology Cluster concept says that the technology driven individuals use cluster of technologies simultaneously to enhance their technical knowledge. A research in USA studied online shopping, banking, investing and electronic payment system and found that prior technical knowhow is one of the key factors for adoption decision (Eastin's 2002). Here it should be noticed that prior experience with media shopping has positive influence on the mobile shopping purchase decisions (Korgaonkar and Moschis, 1987; Shim and Drake, 1990). Despite the prospect of Mobile Shopping, the area has several factors unexplored. There are a number of generalized views on mobile commerce, marketing and retailing (e.g. Shankar et al., 2010; Varnali and Toker, 2010). Specifically with reference to mobile phones, there are few studies that evaluate \& examine consumer attitudes towards mobile phone marketing (Chiem et al., 2007; Persaud and Azhar, 2012).

\section{OBJECTIVES OF THE STUDY}

1. To understand and develop a Mobile Shopping Acceptance Model.

2. To study the factors which influence the Mobile Shopping Behaviour.

3. To analyze and compare the variables of past and present in TPB.

4. To trace the dependence of constructs on the Intention for Mobile Shopping.

\section{RESEARCH METHODOLOGY}

\section{Sample}

A sample of 120 mobile shoppers was taken from the population of residents of Greater Noida, UP. There were $66 \%$ male respondents and $34 \%$ women respondents. The largest group of respondents was between the ages of 26 and 30 years old (48\%). $32 \%$ of respondents indicated that they use mobile for frequent online shopping. As far as education is concerned $62 \%$ are Postgraduates and $49 \%$ are salaried.

*All figures are mentioned are rounded off to the nearest integer.

\section{Measures}

Mobile shopping acceptance model is developed and used to measure the key factors of mobile shopping behaviour. It is based on TRA and TPM. A five pointer Likert Scale is used

(1) Strongly Disagree (2) Somewhat Disagree (3) Neutral (4) Somewhat Agree (5) Strongly Agree

\section{Hypotheses}

H1. Attitude toward using mobile shopping service is positively related intention to shop using mobiles.

H2. Subjective Norms (Societal influence) is positively related to intention to shop using mobiles.

H3. Perceived Behavioural Control is positively related to behavioural intention to shop using mobiles.

\section{RESULTS AND ANALYSIS}

\begin{tabular}{|c|c|c|c|c|}
\hline Constructs & Indicators & $\begin{array}{c}\text { Factor } \\
\text { loadings }\end{array}$ & $\begin{array}{l}\mathbf{N = 1 2 0}) \\
\text { Composite } \\
\text { Reliability } \\
\end{array}$ & $\begin{array}{c}\text { Chronba } \\
\text { ch Alpha } \\
(\alpha) \\
\end{array}$ \\
\hline \multirow{4}{*}{$\begin{array}{c}\text { Attitude } \\
\text { towards } \\
\text { Behaviour }\end{array}$} & $\begin{array}{l}\text { AB1. It is } \\
\text { good to shop } \\
\text { by Mobile }\end{array}$ & 0.93 & 0.79 & 0.97 \\
\hline & $\begin{array}{c}\text { AB2. I am a } \\
\text { supporter of } \\
\text { mobile } \\
\text { shopping }\end{array}$ & 0.96 & & \\
\hline & $\begin{array}{c}\text { AB3. It is wise } \\
\text { to shop by } \\
\text { Mobile }\end{array}$ & 0.92 & & \\
\hline & $\begin{array}{c}\text { AB4. I have a } \\
\text { strong feeling } \\
\text { towards } \\
\text { mobile } \\
\text { shopping }\end{array}$ & 0.97 & & \\
\hline \multirow[t]{2}{*}{$\begin{array}{c}\text { Subjective } \\
\text { Norms }\end{array}$} & $\begin{array}{l}\text { SN1. My } \\
\text { influence } \\
\text { group think } \\
\text { that I should } \\
\text { use mobile } \\
\text { shopping } \\
\text { SN2. As my } \\
\text { friends shop } \\
\text { so I should do } \\
\text { mobile } \\
\text { shopping }\end{array}$ & 0.89 & 0.93 & 0.92 \\
\hline & $\begin{array}{l}\text { SN3. My } \\
\text { Family } \\
\text { Members } \\
\text { think that I } \\
\text { should shop } \\
\text { through } \\
\text { mobiles }\end{array}$ & 0.92 & & \\
\hline \multirow{3}{*}{$\begin{array}{c}\text { Perceived } \\
\text { Behavioural } \\
\text { Control }\end{array}$} & $\begin{array}{c}\text { PB1. I have a } \\
\text { mobile to } \\
\text { access } \\
\text { shopping sites }\end{array}$ & 0.61 & 0.8 & 0.78 \\
\hline & $\begin{array}{l}\text { PB2. It is easy } \\
\text { for me to use } \\
\text { the current } \\
\text { system for } \\
\text { mobile } \\
\text { shopping }\end{array}$ & 0.9 & & \\
\hline & $\begin{array}{l}\text { PB3. I know } \\
\text { how to shop } \\
\text { through } \\
\text { mobiles }\end{array}$ & 0.72 & & \\
\hline
\end{tabular}




\begin{tabular}{|c|c|c|c|c|} 
Intention & $\begin{array}{c}\text { IS1. Given the } \\
\text { opportunity, } \\
\text { My intention } \\
\text { is to shop } \\
\text { through } \\
\text { mobiles }\end{array}$ & 0.94 & 0.74 & 0.96 \\
\cline { 2 - 5 } & $\begin{array}{c}\text { IS2. I intend } \\
\text { my mobile } \\
\text { shopping to } \\
\text { grow in } \\
\text { coming years }\end{array}$ & 0.95 & & \\
\cline { 2 - 5 } & $\begin{array}{c}\text { IS3. Intend } \\
\text { to buy goods } \\
\text { or services via } \\
\text { mobile phone }\end{array}$ & 0.96 & & \\
\hline
\end{tabular}

Hypotheses Testing

\begin{tabular}{|c|c|c|c|c|}
\hline $\begin{array}{c}\text { Hypoth } \\
\text { eses }\end{array}$ & Factors & $\begin{array}{c}\text { Standardiz } \\
\text { ed } \\
\text { Coefficien } \\
\text { ts }\end{array}$ & t-value & p-value \\
\hline H1 & $\begin{array}{c}\text { Attitude } \\
\text { towards } \\
\text { Behaviour }\end{array}$ & $0.769 * *$ & 21.748 & 0.0002 \\
\hline H2 & $\begin{array}{c}\text { Subjective } \\
\text { Norms }\end{array}$ & $0.180 * *$ & 6.257 & 0.0082 \\
\hline H3 & $\begin{array}{c}\text { Perceived } \\
\text { Behavioura } \\
\text { l Control }\end{array}$ & $0.091 *$ & 2.717 & 0.0727 \\
\hline
\end{tabular}

The analysis of $\mathrm{H} 1$ testing showed that the 'Attitude towards Behaviour' influence on 'Intention to Shop' was significant (p-value $<0.01$ ), supporting H1. The impact of 'Subjective Norms' on the 'Intention to Shop' was significant at p-value < 0.01 , supporting H2. The effect of 'Perceived Behavioural Control' on 'Intention to Shop' was significant at p-value < 0.1 , thus, supporting $\mathrm{H} 3$.

\section{Mobile Shopping Acceptance Model}

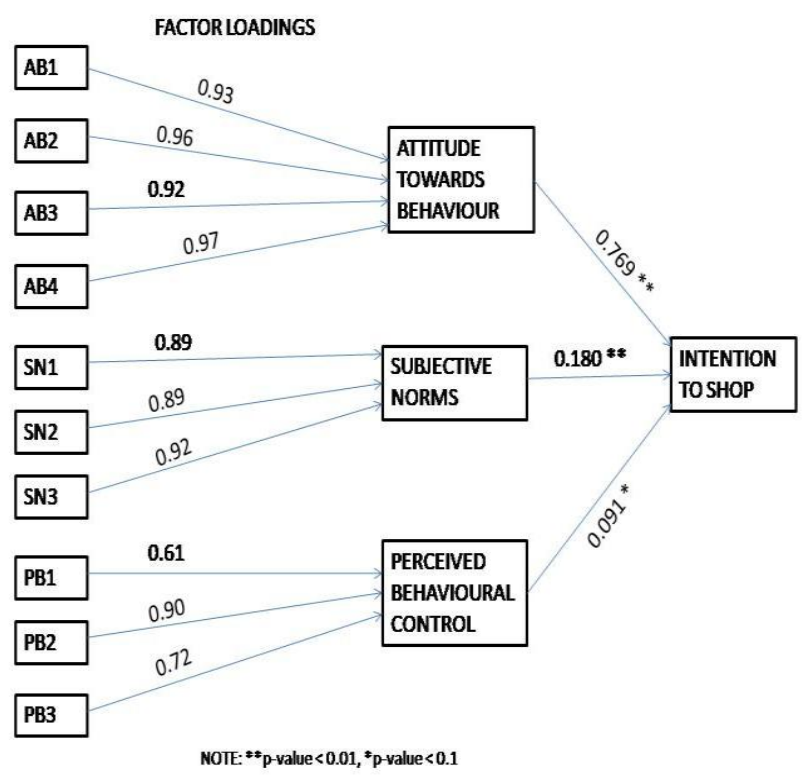

\section{CONCLUSION \& DISCUSSION}

The Mobile Shopping Acceptance Model was developed in the study which was based on Theory of Planned Behaviour
(TPB) and Innovation Diffusion Theory (IDT). It was employed to study the factors affecting the intention of the consumers to shop through mobile. The constructs used in the study were Attitude towards Behaviour, Subjective Norms and Perceived Behavioural Control.

Attitude towards Behaviour was based on the prior knowledge of the consumer towards a specific action. Like 'I am a supporter of mobile shopping' type of action comes from that construct. The standardized coefficient (0.769) shows that the intention to shop through mobiles was $76.9 \%$ dependent on Attitude towards Behaviour, if other factors were ignored.

Subjective Norms basically means the impact of our near and dear ones from the society on our actions. Like 'As my friends shop so I should do mobile shopping' statement perfectly suited that construct. The standardized coefficient $(0.180)$ shows that the intention to shop through mobiles was $18 \%$ dependent on Subjective Norms, if other factors were ignored.

Perceived Behavioural Control refers to the perception of ease with which the technology or anything new can be learnt and used by the consumers. Like 'It is easy for me to use the current system for mobile shopping' type statements summarizes the idea. The standardized coefficient $(0.091)$ shows that the intention to shop through mobiles was $9 \%$ dependent on Perceived Behavioural Control, if other factors were ignored.

The limitation of the study was the respondents were at the moderate level of using mobile shopping services. Since the mobile shopping is still in its nascent stage so its need to be seen how the online shopping services evolve in the future. It will be interesting to see the mobile shopping behaviour when the customers get accustomed to it.

\section{REFERENCES}

1. Mort, G.S. and Drennan, J. (2005), "Marketing m-services: Establishing a usage benefit typology related to mobile user characteristics", Journal of Database Marketing \& Customer Strategy Management, Vol. 12 No. 4, pp. 327-41

2. Kiseol Yang, (2010),"Determinants of US consumer mobile shopping services adoption: implications for designing mobile shopping services", Journal of Consumer Marketing, Vol. 27 Iss 3 pp. 262 - 270

3. Alastair Holmes Angela Byrne Jennifer Rowley , (2013),"Mobile shopping behaviour: insights into attitudes, shopping process involvement and location", International Journal of Retail \& Distribution Management, Vol. 42 Iss 1 pp. 25 - 39

4. Albaum, G., Roster, C.A., Wiley, J., Rossiter, J. and Smith, S.M. (2010), "Developing web surveys in marketing research: does use of forced answering affect completion rates?", Journal of Marketing Theory and Practice, Vol. 18 No. 3, pp. 285-293.

5. Aldas-Manzano, J., Ruiz-Mafe, C. and Sanz-Blas, S. (2009), "Exploring individual personality factors as drivers of M-shopping acceptance", Industrial Management \& Data Systems, Vol. 109 No. 6, pp. 739-757.

6. Barwise, P. and Strong, C. (2002), "Permission-based mobile advertising", Journal of Interactive Marketing, Vol. 16 No. 1, pp. 14-24.

7. Barkhuus, L. and Polichar, V.E. (2011), "Empowerment though seamfulness: smart phones", Personal Ubiquitous Computing, Vol. 15, pp. 629-639.

8. William C. McDowell, Rachel C. Wilson, Charles Owen Kile. 2016. An examination of retail website design and conversion rate. Journal of Business Research 69:11, 4837-4842 
9. Michael Groß. 2015. Exploring the acceptance of technology for mobile shopping: an empirical investigation among Smartphone users. The International Review of Retail, Distribution and Consumer Research $25: 3,215-235$

10. Patrick Hille, Gianfranco Walsh, Mark Cleveland. 2015. Consumer Fear of Online Identity Theft: Scale Development and Validation. Journal of Interactive Marketing 30, 1-19

11. Kiseol Yang, (2010),"Determinants of US consumer mobile shopping services adoption: implications for designing mobile shopping services", Journal of Consumer Marketing, Vol. 27 Iss 3 pp. 262 - 270

12. Lu, H.-P. and Su, P.Y-J. (2009), "Factors affecting purchase intention on mobile shopping websites", Internet Research, Vol. 19 No. 4, pp. 442-458

13. Persaud, A. and Azhar, I. (2012), "Innovative mobile marketing via smartphones: are consumers ready?", Marketing Intelligence and Planning, Vol. 30 No. 4, pp. 408-443

14. Kuo, Y. and Yen, S. (2009), "Towards an understanding of the behavioral intention to use $3 \mathrm{G}$ mobile value-added services", Computers in Human Behavior, Vol. 25, pp. 103-10

15. Hsi-Peng Lu Philip Yu-Jen Su, (2009),"Factors affecting purchase intention on mobile shopping web sites", Internet Research, Vol. 19 Iss 4 pp. $442-458$

\section{AUTHORS PROFILE}

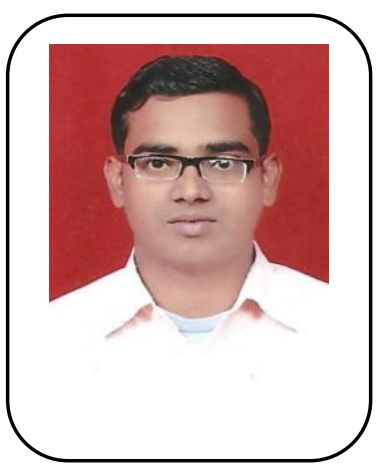

Vikram Kumar Sharma

Assistant Professor

Pursuing PhD from IIT-ISM, Dhanbad

UGC-NET; MBA; B.Sc.(H) Physics,

JEMTEC, Greater Noida.

Vikram Kumar Sharma is a Managemen professional pursuing $\mathrm{PhD}$ from IIT-ISM, Dhanbad. His key interest areas includes Statistics, Operations Research, Supply Chain Management, Production anc Operations Management. $\mathrm{He}$ has keen orientation towards business research and has good foundation in Computer Applications. He has a mixed exposure of 7 years in Industry and Academics.

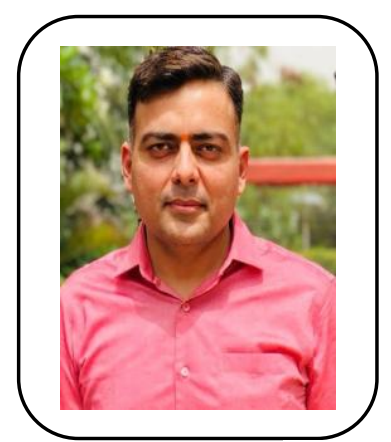

Dr. Arun Kumar Singh

$\mathrm{Ph} . \mathrm{D} / \mathrm{MBA} / \mathrm{MSW}$

HoD-Management Studies

JEMTEC, Greater Noida.

A result oriented management professional with specialization in Marketing, Retail \& General Management served at different positions in various academic institutions \& Industry and having more than 14 Years of experience. He has published more than 20 research papers in national, international journals of repute \& in conference proceedings. He has also done research projects with HCL Perot/ Shri Ram Pistons Ltd. /YMCA India/ ICICI Asset Management/Nestle India/D-Mall/Reed Infomedia/Times of India/ GMR Infra. His research interests include Consumer Buying Behaviour and Retail. 